\title{
Dataset compilation by GRASS GIS for thematic mapping of Antarctica: Topographic surface, ice thickness, subglacial bed elevation and sediment thickness
}

\author{
Polina Lemenkova
}

Schmidt Institute of Physics of the Earth, Russian Academy of Sciences. Department of Natural Disasters, Anthropogenic Hazards and Seismicity of the Earth. Laboratory of Regional Geophysics and Natural Disasters (Nr. 303). Bolshaya Gruzinskaya St. 10, Bld. 1, Moscow, 123995, Russian Federation

\begin{abstract}
This paper presents the GRASS GIS-based thematic mapping of Antarctica using scripting approach and associated datasets on topography and geophysics. The state-ofthe art in cartographic development points at two important aspects. The first one comprises shell scripting promoted repeatability of the GIS technique, increased automatization in cartographic workflow, and compatibility of GRASS with Python, PROJ and GDAL libraries which enables advanced geospatial data processing: converting formats, re-projecting and spatial analysis. The second aspect is that data visualization greatly influences geologic research through improving the interpretation between the Antarctic glaciation and surface. This includes the machine learning algorithms of image classification enabling to distinguish between glacier and non-glacier surfaces through automatically partitioning data and analysis of various types of surfaces. Presented detailed maps of Antarctic include visualized datasets from the ETOPO1, GlobSed, EGM96 and Bedmap2 projects. The grids include bed and surface elevation, ETOPO1-based bathymetry and topography, bed, ice and sediment thickness, grounded bed uncertainty, subglacial bed elevation, geoid undulations, ice mask grounded and shelves. Data show the distribution of the present-day glacier, geophysical fields and topographic landforms for analysis of processes and correlations between the geophysical and geological phenomena. Advances in scripting cartography are significant contributions to the geological and glaciological research. Processing high-resolution datasets of Southern Ocean retrieved by remote sensing methods present new steps in automatization of the digital mapping, as presented in this research, and promotes comprehensive monitoring of geological, permafrost and glacial processes in Antarctica. All maps have been plotted using GRASS GIS version 7.8. with technical details of scripts described and interpreted.
\end{abstract}

Key words: Antarctic, GRASS GIS, script, cartography, mapping, topography, ETOPO1, ice shelf thickness, sedimentation, geoid, geophysics

DOI: $10.5817 / \mathrm{CPR} 2021-1-6$

\footnotetext{
Received December 7, 2020, accepted June 12, 2021.

"Corresponding author: P. Lemenkova <pauline.lemenkova@gmail.com>

Acknowledgements: The author expresses her gratitude to the editor and two anonymous reviewers for processing and editing the paper, providing useful comments, corrections and suggestions that improved the manuscript. This research has been implemented into the framework of the project No. 0144-2019-0011, Schmidt Institute of Physics of the Earth, Russian Academy of Sciences.

Conflict of interests: The author declares no conflict of interests.
} 


\section{Introduction}

The aim of this paper is to present thematic mapping of Antarctica using shell scripting by GRASS GIS and open highresolution datasets. Data visualization is a key issue in Polar studies which largely include geologic and glacial research. Effective mapping is a key tool in Earth sciences as it enables correct interpretation of the findings, helps to better understand the correlation between the geological processes, and points at hydrological and environmental issues. The concepts of cartography and thematic GIS applications are ever-evolving with recent advances in automatization of data visualization which implies scripting techniques.

The onset of the automatization in cartography took place as early as in the 1970 s with rapid development of computerization (e.g. Babcock 1978, Williams 1987, Hernandez 1994) and is being continuously updated along with contemporary advances in GIS and RS and progress in computational techniques (Kloser et al. 2001, Takeda et al. 2002, Schenke and Lemenkova 2008, Tedesco 2009, Lemenkov and Lemenkova 2021a, Klaučo et al. 2013b, 2014, 2017; Ladroit et al. 2020, Johnson et al. 2020). It was followed by further methodological development of geoinformatics which resulted in a combination of spatial analysis with statistical libraries of the programming languages (Greene et al. 2017, Lemenkova 2020d, Brus 2019).

An increasing expectation of scripting cartography is that new, machine learning methods contribute to the development of geospatial visualization through automated geographical data analysis of big complex vector and raster datasets. Such automatization delivers faster and more accurate cartographic results compared to the handmade traditional mapping. As a result, scripting cartographic approaches add to the geological science new datasets which in turn provide new background for data interpretation. Often, the geological research is based on using traditional GIS with graphical user interface (GUI) which often involves a complex process of preparing maps and layouts. The advantages of scripting methods in cartography consists in repeatability of the code which fastens and smoothens data analysis, and contributes to the dissemination of the new findings through new maps. This paper demonstrates the importance of using and applying scripting based cartographic methods in topographic and geophysical visualization with a case study of Antarctic.

Many studies on Polar and marine systems undertake exploit surveys during the expeditions and collect datasets by the multibeam echo-sounders for seafloor mapping, data sampling, sorting, processing and post-processing (Aquilina et al. 2013, Gauger et al. 2007, Gohl et al. 2006a, b; Kuhn et al. 2006, Bell et al. 2016, Gales et al. 2014). Others are often supported by the statistical analysis and visualization of the datasets (Lemenkova 2019a, b; 2021a; Klaučo et al. 2013a), or present tectonic reconstructions based on geochemical analysis (Leat et al. 2009). However, it should be pointed out that mapping better presents graphical summaries of geospatial data distribution that enable to highlight correlations between the geological and glacial datasets. The practice, though, is that some works that do include maps are often based on previously made maps. Others include at least mapping based on the traditional GIS (Suetova et al. 2005, Lemenkova 2011, Lemenkova et al. 2012).

Using shell scripts and advanced methods of data processing (e.g. converting formats by GDAL library, re-projecting by PROJ) has revolutionized the contemporary cartography. However, in contrast with the common mapping practice, using scripting in GIS is less known. 


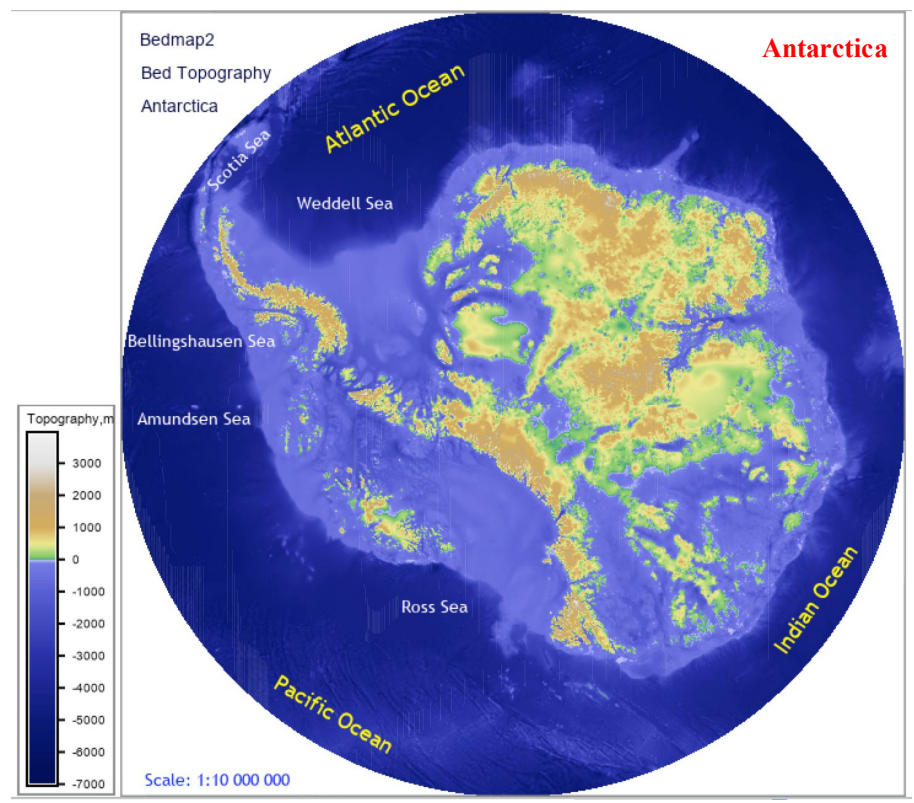

Fig. 1. Bed topography and bathymetry, Antarctica. GRASS GIS.

At the same time, the advantages of using shell scripts, such as GMT or GRASS GIS, machine learning algorithms, and open datasets in geologic studies are evident and presented in a variety of papers (e.g. Becker 2005, Bohoyo et al. 2019, Lemenkova 2020a, b, c; Bivand 2019, Jordan et al. 2013, Wessel et al. 2019). It becomes especially actual nowadays due to the general trend of the distance-based research which requires open datasets and free software. This paper aims to fill the gap by demonstrating the use of scripting approach of GRASS GIS for plotting thematic series of maps of Antarctica using open datasets. Besides general map of the study area (Fig. 1), these include bed topography (Fig. 2), surface elevations (Fig. 3), geoid model (Fig. 4), ice mask grounded and shelves (Fig. 5), sediment thickness (Fig. 6), ETOPO1 topography (Fig. 7), and grounded bed uncertainty (Fig. 8).

A motivation for developing these maps are the advantages presented by the
GRASS GIS that enables to process updated recent data on Antarctica using a scripting approach with respect to having a scripting methodology of drawing these maps that exhibits variations in the ice sheet according to the modern data: increase, decrease and homogeneous distribution of the ice in various regions of Antarctica and surrounding shelf areas. Second, compatible visualization of the geophysical, geological, topographic and glaciological data becomes possible due to versatility and flexibility of the GRASS GIS syntax in general, as well as open source availability of the updated datasets on Antarctic geophysical settings.

There has been a significant amount of Antarctic research into glacial dynamics (Cook and Vaughan 2010), trends in tectonic processes (Eagles et al. 2009), seafloor geomorphology (Camerlenghi et al. 2001), ice shelf thickness (Griggs and Bamber 2011) and seabed bathymetry (Hodgson et al. 2019). However, cartography-focused studies into Antarctic map- 
ping are limited (Bamber et al. 2009). A systematic approach to search in the topographic and geologic datasets is the first step in Antarctic research. In this regards, the Bedmap2 by British Antarctic Survey[1] is one of the most comprehensive open geospatial resources specifically for Antarctica. It presents a set of open grids in-

\section{Background: Study area}

The study area is focused on Antarctica, which geology remains mostly unknown due to the ice sheet covering it by the layer with thickness reaching up to $3.5 \mathrm{~km}$ (Fretwell et al. 2013). The outcrops of bedrock are only occasional which makes the study of the continent complicated and requires remote sensing and digital methods of data processing. Antarctica is schematically composed of three major geologic-tectonic structures: 1) East Antarctica; 2) Transantarctic Mountain belt; 3) West Antarctica (Jordan et al. 2017).

The continental configuration of Antarctica was largely shaped during the Gondwana breakup, which significantly affected its hydrology, climate settings, cryosphere, and geology (Riley et al. 2020). The disintegration of Gondwana led to the isolation of Antarctica in a polar position (Storey et al. 2013). Thus, the consequences of the Gondwana separation on the hydrological settings can be illustrated by opened major oceanic gateways (Lawver and Gahagan 2003). These include Drake Passage and the Tasmanian gateway separating South America, Australia and Antarctica, which initiated modern circulation pattern around Antarctica (Bohoyo et al. 2016). Climate changes significantly affected glacial settings of Antarctica including the geometry and distribution of the ice sheets (Johnson et al. 2012).

The topography of Antarctica consists of several blocks which basement was formed in Precambrian (Dalziel 1992). West Antarctica includes two distinct largesized topographic depressions covered by cluding geological, geophysical and topographic data. Other useful datasets include ETOPO1, EGM-96, EGM-2008, GEBCO, GlobSed, SRTM, GLOBE. The British Antarctic Survey includes a variety of data on such categories as Hydrosphere, Land Surface, Oceans, Paleoclimate, Solid Earth and more.

ice shelves as West Antarctica basins: 1) Ross Ice Shelf, a southern depression in the Ross Sea; and 2) Ronne Ice Shelf, a northern depression in the Weddell Sea. The southern basin is considered as one of the world's largest crustal extensional areas (Behrendt 2013). The combined effects of the complex geological and geophysical processes resulted in significant extension of crust and magmatism in West Antarctica (Cande et al. 2000). The West Antarctic rift system, one of the largest active continental rift systems, was formed during late Mesozoic and Cenozoic extension of the West and East Antarctica (Cande et al. 2000). The topography of East Antarctica includes several ice sheets located along the coasts of the continents: Queen Maud Land, Enderby Land, Queen Mary Land, Wilkes Basin.

Geophysical processes, mechanisms of the geologic formation are still controversial and bring many disputes into the publications on Antarctic geology, tectonic formation, glacial distribution, and hydrological regime. This makes modelling of the Antarctica using high-resolution datasets to be actual contribution to the polar studies. Since the focus of this study is on Antarctic mapping by scripting cartography, this paper omits the additional details on tectonic evolution and geologic settings of Antarctica which can be found in the studies from last decade (see e.g. Gales et al. 2016, Leat et al. 2018, Flowerdew et al. 2012, Vaughan et al. 2012, Gibson et al. 2010). 


\section{Material and Methods}

The maps presented in this research were made using GRASS GIS (Geographic Resources Analysis Support System) originally developed by M. Neteler

\section{Data}

A range of geospatial data resources are now available including thematic websites on Antarctic and Polar research, PANGEA Data Publisher for Earth and Environmental Science, published datasets including those on Antarctica, and repositories with e-journals. The bathymetric data include GEBCO grid, and topographic regional improvements (e.g. Graham et al. 2011) of the selected areas in Antarctica and IBCAO for the North Pole.

The geophysical data include gravity grids (Smith and Sandwell 1995, Sandwell and Smith 2005, 2009; Sandwell et al.
(Neteler 2000, Neteler et al. 2008) and continuously supported by GRASS Development Team (2018 - [2]) since then.
2014), related datasets, such as EGM-96, EGM-2008, and archiving geophysical datasets (Hamilton et al. 2019). The sediment thickness is computed in global grid (Divins 2003), glacial sediment thickness grids cover selected regions of the World ocean (Lindeque et al. 2016, Wobbe et al. 2014) such approaches are used in existing practical applications (Rosenheim et al. 2008, Lemenkova 2020e). These data add to the general pool of Earth data resources which can also be used in regional studies of Antarctica.

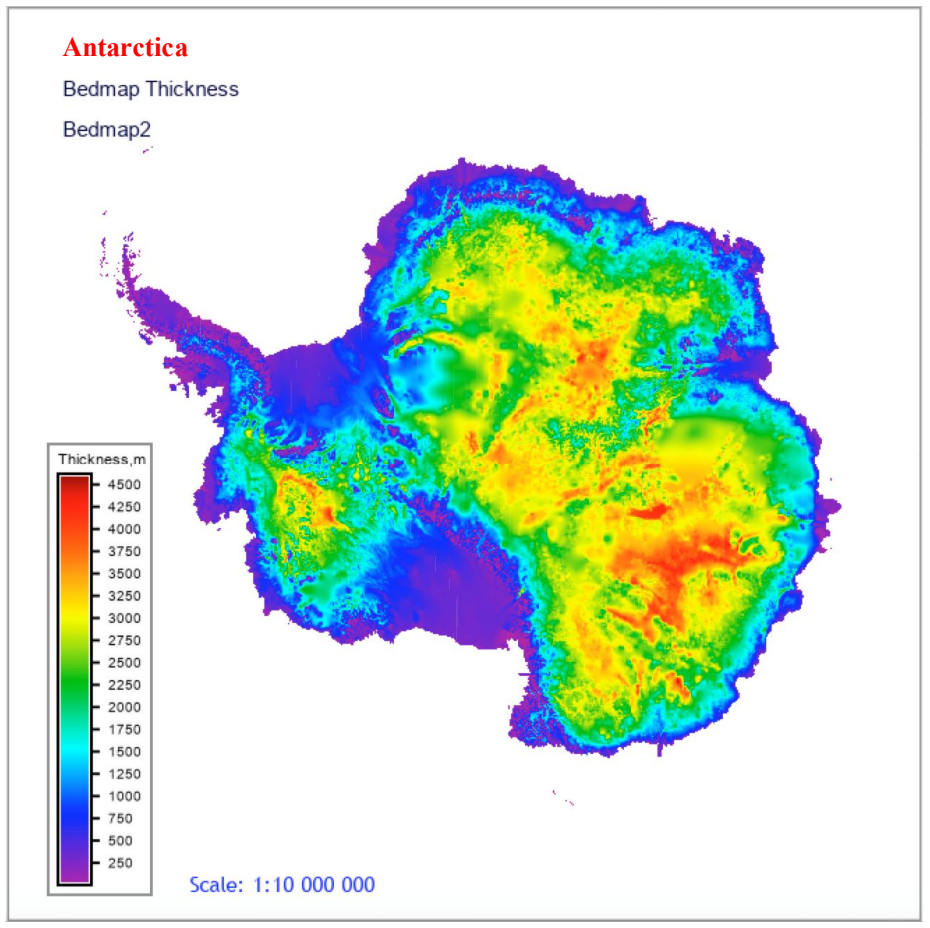

Fig. 2. Map of bed topography of Antarctica. Mapping: GRASS GIS. 
Particularly, the data used in this paper include the bed grid of the Antarctica (Lythe et al. 2000, 2001), ETOPO1 global relief model of Earth's surface that integrates land topography and the ocean bathymetry with 1 arc-minute resolution (Amante and Eakins 2009). Other sources

\section{Methods}

Various different GRASS GIS modules have been applied in scripting. The project was generated in GRASS GIS using following workflow. The folder was created for all stored files that GRASS used for creating maps in Polar stereographic projection. The the directory structure was assigned by GRASS and consisted from the main folder (location: Antarctica) and are sediment thickness from the GlobSed5 grid of total sediment thickness in the World's oceans (Straume et al. 2019), and geoid dataset available as a part of the Bedmap2 project (Fretwell 2012) which includes ice thickness, subglacial topographic model of Antarctica and geophysical data.

subdirectories: mapsets. The mapset 'Permanent' was used as an archive for all maps, while other thematic mapsets were generated in the respective subdirectories, e.g.: 'Bathymetry', 'Bedmap', 'Surface Topography', 'Geoid', 'Sediment thickness', 'ETOPO1'). The workflow can be summarized as follows.

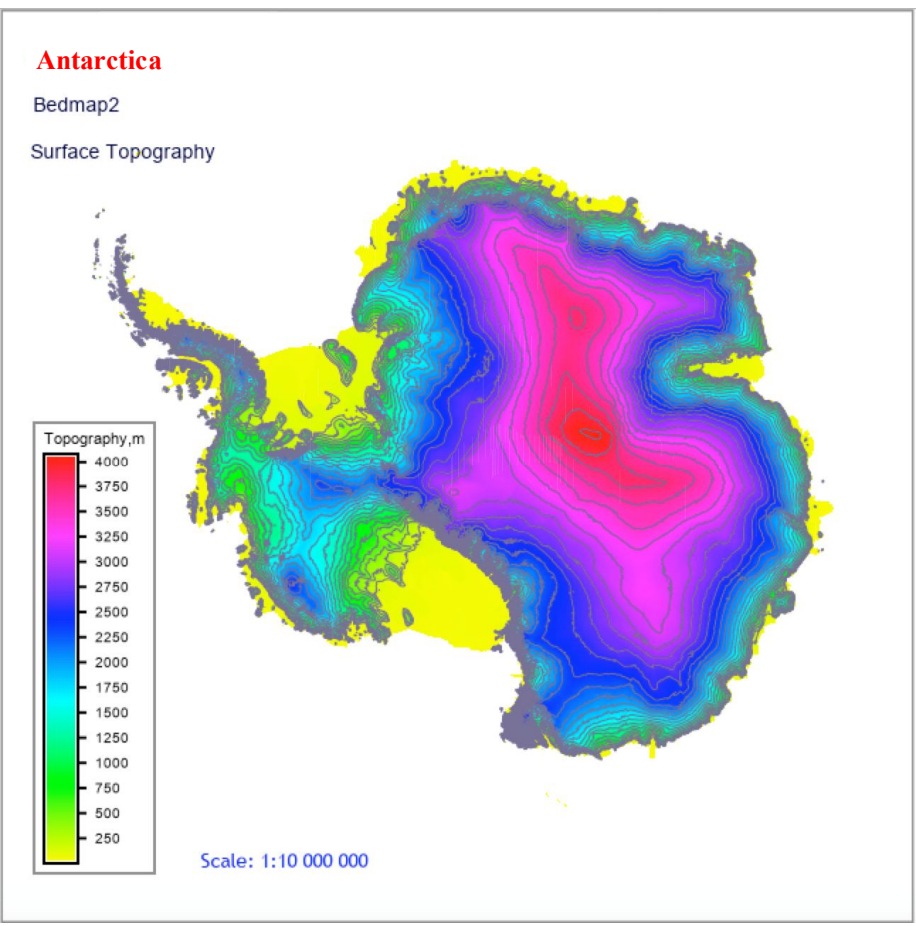

Fig. 3. Surface topography of Antarctica. Mapping: GRASS GIS.

First, the data using the GDAL library (Geospatial Data Abstraction Library - [3]) using a 'gdalwarp' utility to convert GeoTIFF file from XY Cartesian to WGS84, from NetCDF to GeoTIFF by following code (example for ETOPO1 grid converting): gdalwarp -t_srs EPSG:4326 a_relief.nc a_relief_wgs84.tif -overwrite. 
Second, the data were inspected for the extent, range and origin by metadata using 'gdalinfo' utility: gdalinfo a_relief_wgs84.tif. The unnecessary data were removed (those with not suitable spatial coverage or lack of data, such as 'bedmap2_rockmask.tif', 'grav_27.1.img' gravity data) and the following remained in the working folder: bedmap2_bed.tif, bedmap2_coverage.tif, ETOPO1_Ice_g_gmt4.grd, bedmap2_grounded bed_uncertainty.tif, bedmap2_icemask_grounded_and_shelves.tif, bedmap2_thickness. tif, bedmap2_surface.tif, gl04c_geiod_to_WGS84.tif. The maps were generated using these data. The grids shown the extent of the data used for selecting the color palette and the step in the breaks useful in legends.

Third, the data were re-projected to the Universal Polar Stereographic (UPS) projection by the following code: 'gdalwarp -t_srs '+proj=ups +south +datum=WGS84' a_relief_wgs84.tif a_relief_ups.tif -overwrite' where the '+south' flag means the necessary remark for the South polar aspect, since the projection is suitable for the both poles.

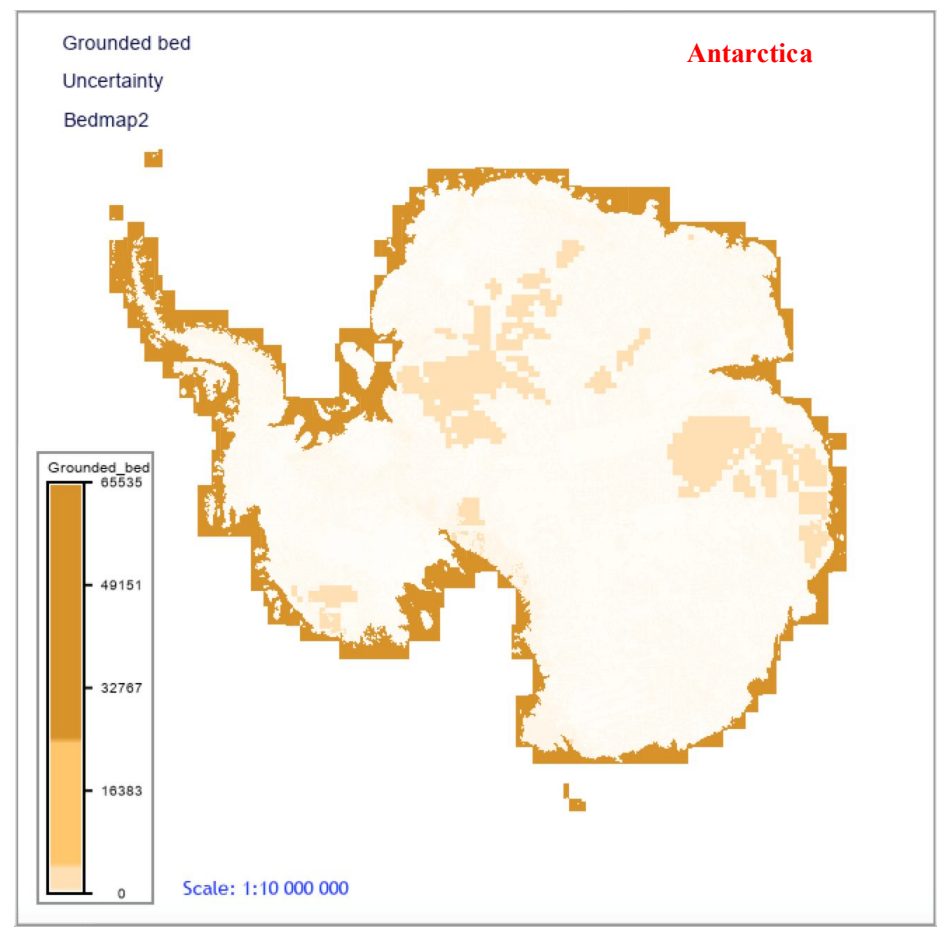

Fig. 4. Geoid undulations, Antarctic region. Mapping: GRASS GIS.

The data were then imported into a project using following code: 'r.in.gdal a_relief_ups.tif out=a_relief_ups title="Antarctic ETOPO1" -overwrite' and then inspected using the code 'r.info a_relief_ups'. The boundary for the geographic region of Antarctica were defined by the 'g.region' module: 'g.region raster=a_relief_ups -p'.

The next step included the preparation of the window for plotting using following codes: 'd.erase', ' d.mon wx0', 'r.colors a_relief_ups col=byr', 'd.rast a_relief_ups'. These commands of GRASS GIS defined the color palette for the map (here: the topographic map based on the ETOPO1 shown in Fig. 7) and visualization is on the screen. 
The cartographic elements are essential components of every map. They were plotted using special modules of GRASS GIS, explained as follows. The title was added using the module 'd.title' as follows: d.title map=a_relief_ups | d.text text="Antarctic" color="red" size $=3$. The legend was added using module 'd.legend' as follows: 'd.legend raster $=$ a_relief_ups range $=-7160,4763-\mathrm{d}$ title $=$ Topography, $\mathrm{m}$ title_fontsize $=8 \mathrm{font}=$ Arial fontsize $=7-\mathrm{t}-\bar{b}$ bgcolor $=$ white label_step $=1000$ border_color $=$ gray thin $=8$ '.

The isolines were modeled from the raster grid every 2,000 meters using the 'r.contour' GRASS GIS module which plots a vector contour lines from a raster map, as follows: 'r.contour a_relief_ups out=reliefAnt step=2000 -overwrite'. Then, the visualization was done (as additional elements) on the map by 'd.vect' module: 'd.vect reliefAnt color='100:93:134' width=0'. The text annotations were added using following commands (here, the example of Scotia Sea): "d.text text="Scotia Sea" color=blue size $=2.0$ font $=$ "Trebuchet MS" rotation $=45$ '.

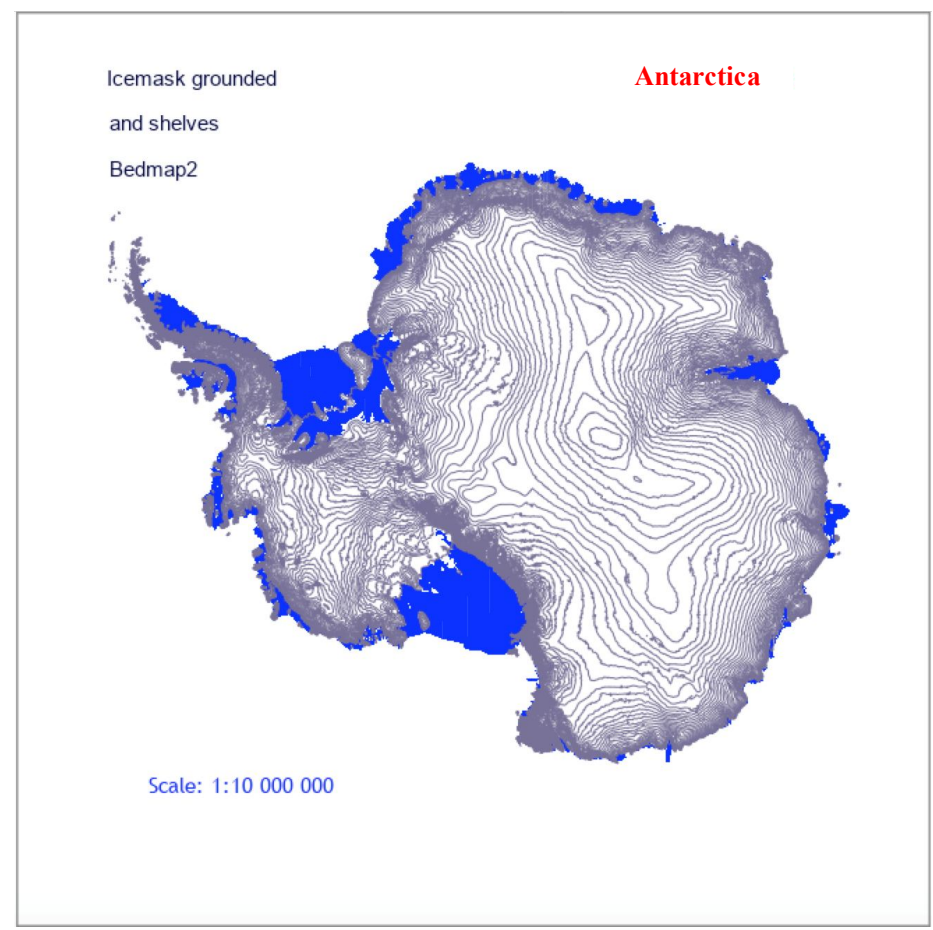

Fig. 5. Ice mask grounded and shelves in Antarctica. GRASS GIS.

Such technical cartographic approach of GRASS GIS syntax was followed for plotting of all the presented eight maps in this study. It should be pointed out that scripting techniques enable to reuse the script for the data processing which largely automates the workflow of the cartographer. Specifically, the machine and deep learning solutions of GRASS GIS enable to easy use of open source code to plot maps as smarter and faster Earth science workflow. Due to the automatization of the code, the shell script listings of the GRASS GIS can be reused for plotting similar maps, which makes the process of mapping more effective and fast. Along with open source availability and integration with GDAL/PROJ libraries and Python, it is one of the serious advantages of the GRASS GIS over the traditional commercial GIS. 


\section{Results and Discussion}

The topographic and ice shelve maps were visualized using GRASS GIS for investigation of the geophysical settings of the region using scripting cartographic approach. Existing maps from previous studies played a critical role in visualizing Antarctic geology and geomorphic landforms, geologic modeling (e.g. basal ice age) and study of hydrosphere and cryosphere of the Southern Pole. However, the novelty of the present study is the new technical approach in GIS mapping by shell script without GUI. Such approach improved the methodological techniques of GIS, intended to contribute to the existing studies and add new results by visualizing thematic maps by high-resolution datasets on geo- physical, geological (sediments), topographic and glaciological data.

The inspection of the data demonstrates following findings. The grid visualizing bed topography in Fig. 1 (r.info bedmap2 bed) shows the data range from $-7,054$ up to 3,972 including both bathymetric and topographic values. The complexity of the topographic settings formed as a result of long-term geologic and tectonic evolution of the continent is well reflected in its modern relief. The topographic elevations in Antarctica are largely controlled by the tectonic plate dynamics and the processes of their subduction and mass distribution. Fig. 1 shows the modern relief map of the Antarctica.

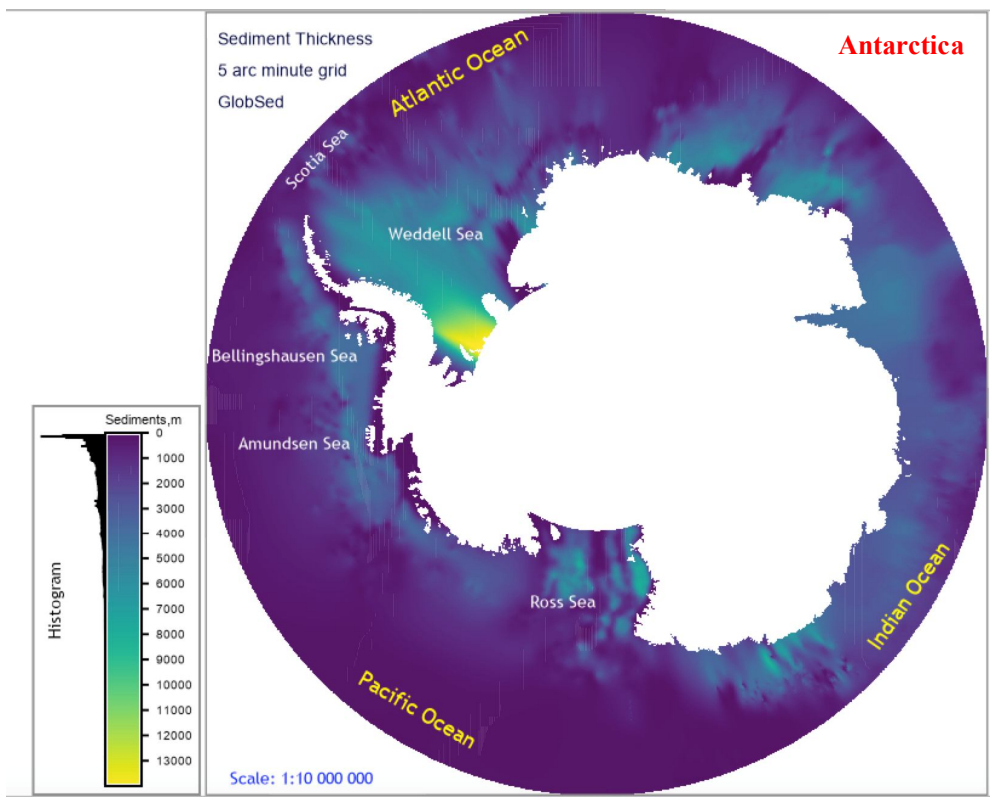

Fig. 6. Sediment thickness in Antarctic region. Mapping: GRASS GIS.

The map of the bed topography in Fig. 2 shows data distribution from 0 to 4,621 $\mathrm{m}$ which shows a subglacial topographic model of Antarctica. The inspection of grid showing surface topography in Fig. 3 (r.info bedmap2_surface) shows the data range from 1 to $4,082 \mathrm{~m}$ heights. Therefore, the asymmetric distribution of the topography in West and East Antarctica mirrors general distribution of the continental and oceanic lithosphere types. East Antarctica and the Transantarctic Moun- 
tain belt have higher elevation values while West Antarctica is notable by lower topographic heights, as can be noted in Fig. 3 .

The bed map uncertainty in Fig. 8 reveals the unknown information on bed map data distribution and data coverage (certainty/uncertainty) corresponding to the grid of the Bedmap2 project $(\mathrm{m})$. The ice shelves mask data distribution in Fig. 5 shows the present-day high-resolution ice map of the Antarctic ice sheet in the shelve areas with defined three data types: $0=$ grounded, $1=$ ice shelf, and the rest is the ocean. The isolines shown in grey refer to the elevations of the topographic relief.

The map of sediment thickness in Antarctic in Fig. 6 reveals the significant increase of the sediments in the Weddell Sea which can be explained by the presence of the Ronne Ice Shelf largely contributing to the sediment accumulation and re-distribution in the shelf zone. Compared to other data from the published studies, analysis of the sediment distribution enables to better understand the ice sheet evolution and sedimentation history in Antarctica. Thus, total sediment volume in the Weddell Sea deep-sea basin is estimated by Lindeque et al. (2013) at $3.3-3.9 \times 106 \mathrm{~km}^{3}$. According to findings of Rogenhagen and Jokat (2000), sediment thickness in the western Weddell Sea ranges from $4.8 \pm 0.3$ to $7.3 \pm 0.3 \mathrm{~km}$, but is rather uniform in the eastern continental margin of the Antarctic Peninsula (ca. $\left.52^{\circ}-35^{\circ} \mathrm{W}\right)$.

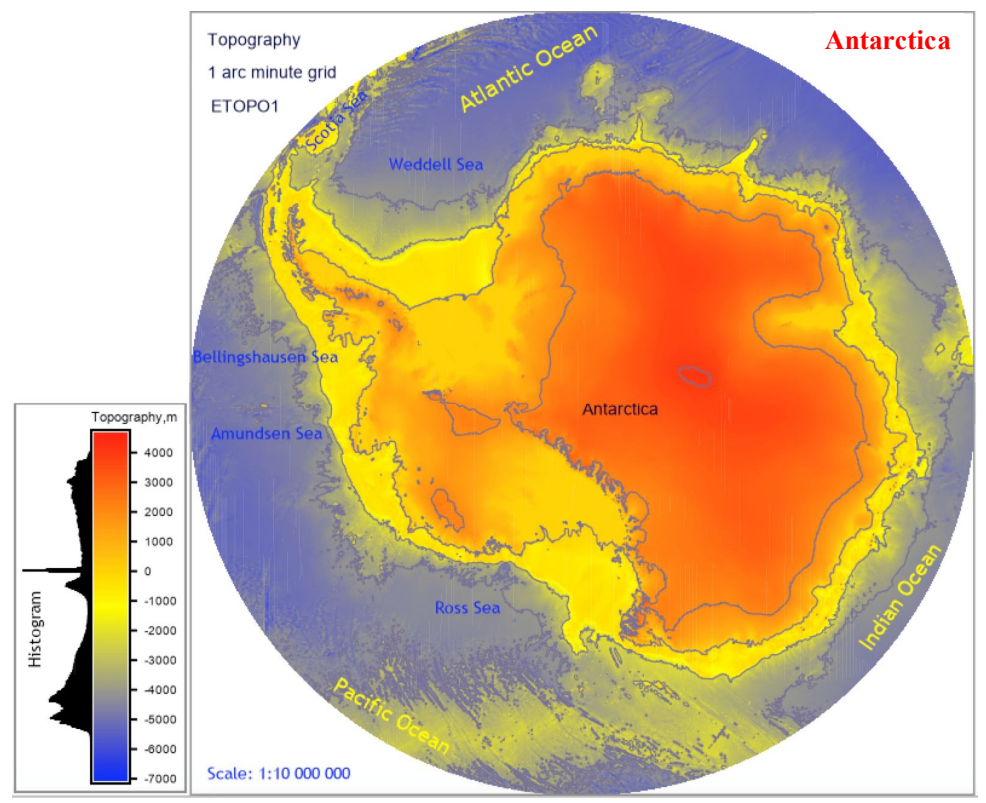

Fig. 7. ETOPO1 topography in Antarctic region. Mapping: GRASS GIS.

Previous studies also proved that the unique sedimentation environment of the SE Weddell Sea is explained by a large catchment area and fast paleo-ice streams that feed the Filchner Ronne Ice Shelf (Huang and Jokat 2016, Lemenkova 2021b). Other factors include turbidity/bot- tom currents and sea level changes. They furthermore detected the sinuous, NE-SWoriented turbidity-contourites that correlate with bathymetric highs over $150 \mathrm{~km}$ wide, $700 \mathrm{~km}$ long, and sediment thickness of up to $2 \mathrm{~km}$. The Cretaceous proto-Weddell Gyre bottom current contributed to the sed- 
iment accumulation as detected by the thick (up to $1130 \mathrm{~m}$ ) pre-glacial seismic units which form a mound in the central Weddell Sea basin and in conjunction with the eroded flank geometry (Lindeque et al. 2013).

Sediment thickness and sedimentation rates are calculated and gridded using multichannel seismic reflection transects by Huang et al. (2014). They shown that the pre-glacial deposition with thicknesses of up to $5 \mathrm{~km}$ was controlled by the tectonic evolution and seafloor spreading besides the terrigenous sediment supply. The data shown a high sedimentation rate in the Weddell Sea with thicknesses of up to $3 \mathrm{~km}$. This may be caused by the formation of the East Antarctic Ice Sheet, which moved to the coast or inner Antarctic shelf (Huang et al. 2014).

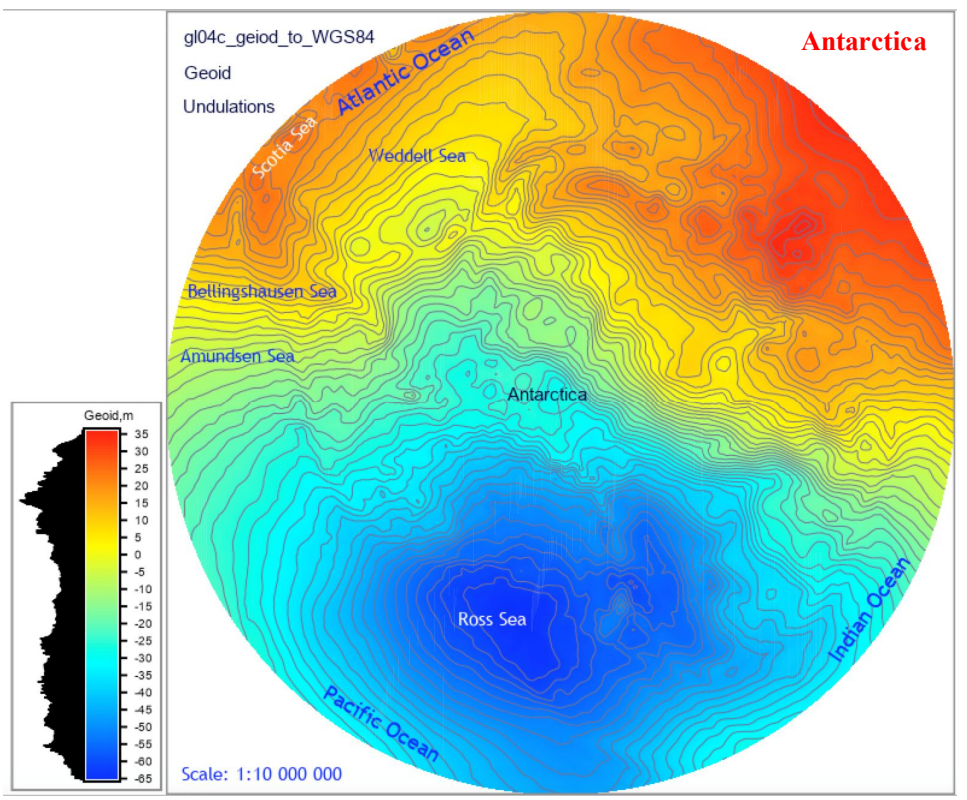

Fig. 8. Grounded bed uncertainty in Antarctica. Mapping: GRASS GIS.

The maximal values here reach up to $14,000 \mathrm{~m}$ of thickness according to the GlobSed5 project. The Ross Sea shows lesser amount of sediments though considerably higher comparing to the other seas of the Southern Ocean with the maximal values reaching $9,000 \mathrm{~m}$. Both depressions of the Ross and Weddell seas have been isostatically readjusted and filled with deposited sediments which proves correlation between the topographic patterns affecting sediment distribution along with regional glacial settings.

The topographic map of Antarctic shown in Fig. 7 is based on the ETOPO1 project with 1 arc min resolution grid. It is plotted using the modeled data of known topography and bathymetry, based on the ETOPO1 topographic compilation (Amante and Eakins 2009). The maps show the Antarctic topography with the isolines plotted every $2000 \mathrm{~m}$ and sidewise histogram on data distribution. The map of geoid undulations in Fig. 4 depicts the geophysical measurements performed in Antarctica and compiled in the Bedmap2 project. It is based on the high-resolution global mean gravity field model of the EIGEN-GL04C, derived from the combination of satellite tracking and surface data. 
The model shows a combination of GRACE (Gravity Recovery and Climate Experiment, a joint mission of NASA and the German DLR) and LAGEOS (Laser Geodynamic Satellite) mission, gravimetry and altimetry surface data. The data show the rough sub-division of Antarctica into two large regions: the region with higher values from -15 to $35 \mathrm{~m}$ (corresponds to the northern part of Antarctica, Weddell

\section{Conclusions}

This paper presented an example of plotting series of the thematic maps of Antarctica using GRASS GIS based on open geophysical and topographic datasets. The compilation of the high-resolution datasets provides new insights into the topographic structure of Antarctica. It furthermore shows that a new approach of scripting cartographic workflow performs more effective to create a series of maps than using traditional commercial GUIbased GIS with often perplexed interface. The scripting based cartography has a straightforward syntax which is user-oriented and direct in mapping techniques.

The attempts of combining logic of programming languages and machine learning approaches to cartography resulted in several outputs such as e.g. combination of machine learning classifiers along with GIS techniques (Motta et al. 2021), AWK language for processing tables from geodata through conversion and formatting (Lemenkova 2019e), modeling links between environmental, biodiversity and climate change impacts (Walther and Huettmann 2021), integration of GRASS GIS, Python, TeX language, or artificial neural networks for geological engineering modeling (Bragagnolo et al. 2020, Lemenkov and Lemenkova 2021b), to mention a few of them.

Moreover, the use of coding marks the onset of scripting era in cartography that significantly facilitate mapping proc-
Sea and the south Atlantic Ocean, compare Fig. 1 and Fig. 4) and a region with lower values from -15 to -65 which corresponds to the very low negative values of geoid. This region includes the Ross Sea, South Pacific Ocean and south Indian Ocean. The variations in the data can be explained by the geophysical settings of the gravity anomalies in South Pole.

ess through fasten coding and absence of complex GUI with often useless and very specific functionality as in traditional GIS software. The main advantage of the shell scripts in cartography consists in their flexibility which is achieved in controlling utilities, using modules with their attributes (set up as 'flags'). The combination of the GRASS GIS codes in a script results in an effective and smooth mapping process that can be repeated for any other territories using flexible move of the coordinates and projecting transformations. A command syntax embedded in GRASS GIS offers a uniform shell programming structure within applications in a variety of tools in geospatial analysis, as demonstrated in this paper with a case study of Antarctica.

The high-resolution data from available sources (Bedmap2, etc) were processed and visualized to plot detailed maps of ice thickness and bed subglacial topography of Antarctica. The presented maps are accompanied with the scripts developed in GRASS GIS and described in Methodology section in detailed for repeatability. New cartographic visualization helps to gain a better understanding of the surface of the Antarctic topography in the regional studies on polar research, as well as the geophysical and glacial studies of the surrounding area which include sea of Antarctica. 
Overall, the evolution of the Antarctic ice sheet thickness was fluctuating and mostly controlled by climatic drivers such as $\mathrm{CO}_{2}$, and sea level forces with a period of ca. 100,000 yr. However, changes in ice sheet volume include a complex interplay of global and local, climatic, environmental and tectonic factors in Late Quaternary Antarctic ice sheet evolution (Tigchelaar et al. 2018, Beltran et al. 2020, Halberstadt et al. 2021). Recently, the Antarctic ice sheet has been experiencing retreat and thaw. For example, the Reedy Glacier (southern Transantarctic Mountains) was significantly thicker multiple times during the mid-to-late Cenozoic, and the West Antarctic Ice Sheet was at least $500 \mathrm{~m}$ higher than today, as reported by Bromley et al. (2010). Furthermore, as reported by Hogg et al. (2017), the Antarctic ice shelves have retreated and suffered collapse in the period of 2010 to 2017. However, comparison of spatial variations shown that ice losses from West Antarctica are compensated by ice gains in East Antarctica. This resulted in the thickening of the ice shelves in Antarctica by an average of $1.3 \mathrm{~m}$ in the past two decades (Hogg et al. 2021).

This study demonstrated the ice sheet current view using recent data and modern tools. The use of shell scripting in cartographic studies have only recently been actively used and this paper contributes to the technical advances of the mapping methodology. It should be also stressed that all the maps are made using available datasets and open source software which is valuable both for researchers and students with research in Antarctica and Southern Ocean. Examples of scripting cartography should include the Generic Mapping Tools (GMT) a cartographic scripting toolset widely used in geophysics. Lemenkova (2019c, d) undertook a cross-sectional survey of the submarine geomorphology of the selected deep-sea trenches and carried out a comparative analysis of their bathymetry in various regions of the Pacific Ocean using GMT scripting. The GRASS GIS, in contrast with GMT, has a graphical user interface (GUI) which enables to operate with data both from the console and using traditional GUI. Other differences between the two programs consists in GRASS having more functionality on remote sensing data processing (including satellite imagery) and spatial analysis (terrain geomorphometric analysis), while GMT is by far the best cartographic toolset for geophysical research and mapping.

\section{References}

Aquilina, A., Connelly, D. P., Copley, J. T., Green, D. R., Hawkes, J. A., Hepburn, L., Huvenne, V. A., Marsh, L., Mills, R. A. and Tyler, P. A. (2013): Geochemical and visual indicators of hydrothermal fluid flow through a sediment-hosted volcanic ridge in the Central Bransfield Basin (Antarctica). Plos One, 8: e54686. https://doi.org/10.1371/journal.pone. 0054686

Amante, C., EAKins, B. W. (2009): ETOPO1 1 Arc-Minute Global Relief Model: Procedures, Data Sources and Analysis. NOAA Technical Memorandum, 19.

BABCOCK, H. C. (1978): Automated cartography data formats and graphics: The ETL experience. The American Cartographer, 5(1): 21-29. https://doi.org/10.1559/152304078784023024

Bamber, J. L., Gomez-Dans, J. L. and Griggs, J. A. (2009): A new 1 km digital elevation model of the Antarctic derived from combined satellite radar and laser data - Part 1: Data and methods. The Cryosphere, 3: 101-111. https://doi.org/10.5194/tc-3-101-2009

BECKER, N. C. (2005): Painting by numbers: A GMT primer for merging swath-mapping sonar data of different types and resolutions. Computers \& Geosciences, 31(8): 1075-1077. https://doi.org/10.1016/j.cageo.2005.02.016 
BeHREndT, J. C. (2013): The aeromagnetic method as a tool to identify Cenozoic magmatism in the West Antarctic Rift System beneath the West Antarctic Ice Sheet - A review; Thiel subglacial volcano as possible source of the ash layer in the WAISCORE. Tectonophysics, 585: 124-136. https://doi.org/10.1016/j.tecto.2012.06.035

Bell, J. B., Woulds, C., Brown, L. E., Little, C. T. S., Sweeting, C. J., Reid, W. D. K. and Glover, A. G. (2016): Macrofaunal ecology of sedimented hydrothermal vents in the Bransfield Strait, Antarctica. Frontiers in Marine Science, 3: 32. https://doi.org/10.3389/ fmars.2016.00032

Beltran, C., Golledge, N. R., Ohneiser, C., Kowalewski, D. E., Sicre, M.-A., Hageman, K. J., SMith, R., Wilson, G. S. and MainiÉ, F. (2020): Southern Ocean temperature records and icesheet models demonstrate rapid Antarctic ice sheet retreat under low atmospheric $\mathrm{CO} 2$ during Marine Isotope Stage 31. Quaternary Science Reviews, 228: 106069. https://doi.org/10.1016/ j.quascirev.2019.106069

BIVAND, R. S. (2019): Scripting and toolbox approaches to spatial analysis in a GIS context. In: Spatial Analytical Perspectives on GIS. https://doi.org/10.1201/9780203739051-3

Bohoyo, F., Larter, R. D., Galindo-Zaldivar, J., Leat, P. T., Maldonado, A., Tate, A. J., Gowland, E. J. M., Arndt, J. E., Dorschel, B., Kim, Y. D., Hong, J. K., FleXas, M. M., Lopez-Martinez, J., Maestro, A., Bermudez, O., Nitsche, F. O., Livermore, R. A. and RiLEY, T. R. (2016): Bathymetry and geological setting of the Drake Passage. BAS GEOMAP 2 Series. Cambridge, British Antarctic Survey. URL: http://nora.nerc.ac.uk/515070/

Bohoyo, F., Larter, R. D., Galindo-Zaldívar, J., Leat, P. T., Maldonado, A., Tate, A. J., Flexas, M. M., Gowland, E. J. M., Arndt, J. E., Dorschel, B., Kim, Y. D., Hong, J. K., López-Martínez, J., Maestro, A., Bermúdez, O., Nitsche, F. O., Livermore, R. A. and RiLEY, T. R. (2019): Morphological and geological features of Drake Passage, Antarctica, from a new digital bathymetric model. Journal of Maps, 15(2): 49-59. https://doi.org/10.1080/ 17445647.2018.1543618

Bragagnolo, L., Da Silva, R. V. and Grzybowski, J. M. V. (2020): Landslide susceptibility mapping with r.landslide: A free open-source GIS-integrated tool based on Artificial Neural Networks. Environmental Modelling \& Software, 123: 104565. https://doi.org/10.1016/ j.envsoft.2019.104565

Bromley, G. R. M., Hall, B. L., Stone, J. O., Conway, H. and Todd, C. E. (2010): Late cenozoic deposits at Reedy Glacier, Transantarctic Mountains: Implications for former thickness of the West Antarctic Ice Sheet. Quaternary Science Reviews, 29(3-4): 384-398. https://doi.org/ 10.1016/j.quascirev.2009.07.001

BRUS, D. J. (2019): Sampling for digital soil mapping: A tutorial supported by R scripts. Geoderma, 338: 464-480. https://doi.org/10.1016/j.geoderma.2018.07.036

Camerlenghi, A., Domack, E., Rebesco, M., Gilbert, R., Ishman, S., Leventer, A., BrachFeld, S. and DraKe, A. (2001): Glacial morphology and post-glacial contourites in northern Prince Gustav Channel (NW Weddell Sea, Antarctica). Marine Geophysical Research, 22: 417-443. https://doi.org/10.1023/A:1016399616365

Cande, S. C., Stock, J. M., Muller, R. D. and Ishihara, T. (2000): Cenozoic motion between East and West Antarctica. Nature, 404: 145-150.

Cook, A. J., Vaughan, D. G. (2010): Overview of areal changes of the ice shelves on the Antarctic Peninsula over the past 50 years. Cryosphere, 4: 77-98. https://doi.org/10.5194/tc-4$77-2010$

Dalziel, I. W. D. (1992): Antarctica: A tale of two supercontinents? Annual Review of Earth and Planetary Sciences, 20: 501-526. https://doi.org/10.1146/annurev.ea.20.050192.002441

Divins, D. (2003): Total sediment thickness of the world's oceans and marginal seas. NOAA National Geophysical Data Center, Boulder.

Eagles, G., Larter, R. D., Gohl, K. and Vaughan, A. P. M. (2009): West Antarctic rift system in the Antarctic Peninsula. Geophysical Research Letters, 36: L21305, https://doi.org/10.1029/ $2009 \mathrm{gl} 040721$

Flowerdew, M. J., Tyrrell, S., Riley, T. R., Whitehouse, M. J. Mulvaney, R., Leat, P. T. and Marschall, H. R. (2012): Distinguishing East and West Antarctic sediment sources using the 
$\mathrm{Pb}$ isotope composition of detrital K-feldspar. Chemical Geology, 292-293: 88-102. https://doi.org/10.1016/j.chemgeo.2011.11.006

Fretwell, P., Pritchard, H. D., Vaughan, D. G., Bamber, J. L., Barrand, N. E., Bell, R., Bianchi, C., Bingham, R. G., Blankenship, D. D., Casassa, G., Catania, G., Callens, D., Conway, H., Cook, A. J., Corr, H. F. J., Damaske, D., Damm, V., Ferraccioli, F., Forsberg, R., Fujita, S., Gim, Y., Gogineni, P., Griggs, J. A., Hindmarsh, R. C. A., Holmlund, P., Holt, J. W., Jacobel, R. W., Jenkins, A., Jokat, W., Jordan, T., King, E. C., Kohler, J., Krabill, W., Riger-Kusk, M., Langley, K. A., Leitchenkov, G., Leuschen, C., Luyendyk, B. P., Matsuoka, K., Mouginot, J., Nitsche, F. O., Nogi, Y., Nost, O. A., Popov, S. V., Rignot, E., Ripin, D. M., Rivera, A., Roberts, J., Ross, N., Siegert, M. J., Smith, A. M., Steinhage, D., Studinger, M., Sun, B., Tinto, B. K., Welch, B. C., Wilson, D., Young, D. A., Xiangbin, C. and ZiRizzotti, A. (2013): BEDMAP2: improved ice bed, surface and thickness datasets for Antarctica. The Cryosphere, 7: 375-393. https://doi.org/10.5194/tc-7-3752013

FreTwell, P. (2012): BEDMAP 2: Progress, plans and publication. Quaternary International, 279-280(16): 151. https://doi.org/10.1016/j.quaint.2012.08.144

Gales, J. A., Leat, P. T., Larter, R. D., Kuhn, G., Hillenbrand, C.-D., Graham, A. G. C., Mitchell, N. C., Tate, A. J., Buys, G. B. and Jokat, W. (2014): Large-scale submarine landslides, channel and gully systems on the southern Weddell Sea margin, Antarctica. Marine Geology, 348: 73-87. https://doi.org/10.1016/j.margeo.2013.12.002

Gales, J. A., Larter, R. D., Leat, P. T. and Jokat, W. (2016): Components of an Antarctic trough-mouth fan: examples from the Crary Fan, Weddell Sea. Geological Society, London, Memoirs, 46: 377-378. https://doi.org/10.1144/M46.82

Gauger, S., Kuhn, G., Gohl, K., Feigl, T., Lemenkova, P. and Hillenbrand, C. (2007): Swathbathymetric mapping. Reports on Polar and Marine Research, 557: 38-45. https://doi.org/ $10.6084 / \mathrm{m} 9$.figshare. 7439231

GiBSON, L. C., GiBSON, S. and LeAT, P. T. (2010): Melt production and mantle refertilisation above a subduction zone: Direct constraints from Antarctic Peninsula spinel-peridotite xenoliths. American Geophysical Union, Fall Meeting 2010, abstract id. V11F-07

Gohl, K., Eagles, G., Udintsev, G., Larter, R. D., Uenzelmann-Neben, G., Schenke, H.-W., Lemenkova, P., Grobys, J., Parsiegla, N., Schlueter, P., Deen, T., Kuhn, G. and Hillenbrand, C.-D. (2006a): Tectonic and sedimentary processes of the West Antarctic margin of the Amundsen Sea embayment and Pine Island Bay. $2^{\text {nd }}$ SCAR Open Science Meeting, 12-14 July 2006, Hobart, Australia. https://doi.org/10.6084/m9.figshare.7435484

Gohl, K., Uenzelmann-Neben, G., Eagles, G., Fahl, A., Feigl, T., Grobys, J., Just, J., Leinweber, V., Lensch, N., Mayr, C., Parsiegla, N., Rackebrandt, N., Schlüter, P., Suckro, S., Zimmermann, K., Gauger, S., Bohlmann, H., Netzeband, G. and Lemenkova, P. (2006b): Crustal and sedimentary structures and geodynamic evolution of the West Antarctic continental margin and Pine Island Bay. Expeditionsprogramm Nr.75 ANT XXIII/4 ANT XXIII/5, 11-12. https://doi.org/10.13140/RG.2.2.16473.36961

Graham, A. G. C., Nitsche, F. O. and Larter, R. D. (2011): An improved bathymetry compilation for the Bellingshausen Sea, Antarctica, to inform ice-sheet and ocean models. The Cryosphere, 5: 95-106. https://doi.org/10.5194/tc-5-95-2011

Greene, C. A., Gwyther, D. E. and Blankenship, D. D. (2017): Antarctic mapping tools for matlab. Computers \& Geosciences, 104: 151-157. https://doi.org/10.1016/j.cageo.2016.08.003

GrIGGS, J., BAMBER, J. (2011): Antarctic ice-shelf thickness from satellite radar altimetry. Journal of Glaciology, 57(203): 485-498. https://doi.org/10.3189/002214311796905659

Halberstadt, A. R. W., Chorley, H., Levy, R. H., Naish, T., DeConto, R. M., Gasson, E. and KowAlEwSKI, D. E. (2021): $\mathrm{CO}_{2}$ and tectonic controls on Antarctic climate and ice-sheet evolution in the mid-Miocene. Earth and Planetary Science Letters, 564: 116908. https://doi.org/10.1016/j.epsl.2021.116908

HAmilton, M., Wessel, P., TAYloR, B. and Luis, J. (2019): Producing marine geophysical archive files from raw underway data. Computers \& Geosciences, 133: 104321. https://doi.org/ 10.1016/j.cageo.2019.104321 
Hernandez, D. (1994): Qualitative Representation of Spatial Knowledge, Berlin: Springer Verlag. Hodgson, D. A., Jordan, T. A., De Rydt, J., Fretwell, P. T., Seddon, S. A., Becker, D., Hogan, K. A., Smith, A. M. and Vaughan, D. G. (2019): Past and future dynamics of the Brunt Ice Shelf from seabed bathymetry and ice shelf geometry. The Cryosphere, 13: 545-556. https://doi.org/10.5194/tc-13-545-2019

Hogg, A. E., Gilbert, L., Shepherd, A., Muir, A. S. and McMillan, M. (2021): Extending the record of Antarctic ice shelf thickness change, from 1992 to 2017. Advances in Space Research, 68(2): 724-731. https://doi.org/10.1016/j.asr.2020.05.030

Hogg, A. E., Shepherd, A., Cornford, S. L., Briggs, K. H., Gourmelen, N., Graham, J. A., Joughin, I., Mouginot, J., Nagler, T., Payne, A. J., Rignot, E. and Wuite, J. (2017): Increased ice flow in Western Palmer Land linked to ocean melting. Geophysical Research Letters, 44: 4159-4167. https://doi.org/10.1002/2016GL072110

HuAnG, X., Gohl, K. and JOKAT, W. (2014): Variability in Cenozoic sedimentation and paleowater depths of the Weddell Sea basin related to pre-glacial and glacial conditions of Antarctica. Global and Planetary Change, 118: 25-41. https://doi.org/10.1016/j.gloplacha. 2014.03.010

HuanG, X., JOKAT, W. (2016): Middle Miocene to present sediment transport and deposits in the Southeastern Weddell Sea, Antarctica. Global and Planetary Change, 139: 211-225. https://doi.org/10.1016/j.gloplacha.2016.03.002

Johnson, J., Everest, J., Leat, P., Golledge, N., Rood, D. and Stuart, F. (2012): The deglacial history of NW Alexander Island, Antarctica, from surface exposure dating. Quaternary Research, 77(2): 273-280. https://doi.org/10.1016/j.yqres.2011.11.012

Johnson, A., FAHNESTOCK, M. and Hock, R. (2020): Evaluation of passive microwave melt detection methods on Antarctic T Peninsula ice shelves using time series of Sentinel-1 SAR. Remote Sensing of Environment, 250: 112044. https://doi.org/10.1016/j.rse.2020.112044

Jordan, T. A., Ferraccioli, F., Ross, N., Corr H. F. J., Leat, P. T., Bingham, R. G., Rippin, D. M., LE BRocQ, A. and Siegert, M. J. (2013): Inland extent of the Weddell Sea Rift imaged by new aerogeophysical data. Tectonophysics, 585: 137-160. http://dx.doi.org/10.1016/j.tecto. 2012.09.010

Jordan, T. A., Ferraccioli, F. and Leat, P. T. (2017): New geophysical compilations link crustal block motion to Jurassic extension and strike-slip faulting in the Weddell Sea Rift System of West Antarctica. Gondwana Research, 42: 29-48. http://dx.doi.org/10.1016/j.gr.2016.09.009

Klaučo, M., Gregorová, B., Stankov, U., Marković, V. and Lemenkova, P. (2013a): Determination of ecological significance based on geostatistical assessment: a case study from the Slovak Natura 2000 protected area. Open Geosciences, 5(1): 28-42. https://doi.org/10.2478/ s13533-012-0120-0

Klaučo, M., Gregorová, B., Stankov, U., Marković, V. and Lemenkova, P. (2013b): Interpretation of Landscape Values, Typology and Quality Using Methods of Spatial Metrics for Ecological Planning. Environmental and Climate Technologies, October 14, 2013. Riga, Latvia. https://doi.org/10.13140/RG.2.2.23026.96963

Klaučo, M., Gregorová, B., Stankov, U., Marković, V. and Lemenkova, P. (2014): Landscape metrics as indicator for ecological significance: assessment of Sitno Natura 2000 sites, Slovakia. Ecology and Environmental Protection, March 19-20, 2014. Minsk, Belarus, 85-90. https://doi.org/10.6084/m9.figshare.7434200

Klaučo, M., Gregorová, B., Koleda, P., Stankov, U., Marković, V. and Lemenkova, P. (2017): Land planning as a support for sustainable development based on tourism: A case study of Slovak Rural Region. Environmental Engineering and Management Journal, 2(16): 449458. https://doi.org/10.30638/eemj.2017.045

Kloser, R., BaX, N., Ryan, T., Williams, A. and Barker, B. (2001): Remote sensing of seabed types in the Australian South East Fishery; development and application of normal incident acoustic techniques and associated 'ground truthing'. Marine and Freshwater Research, 52: 475-489. http://dx.doi.org/10.1071/MF99181

Kuhn, G., Hass, C., Kober, M., Petitat, M., Feigl, T., Hillenbrand, C. D., Kruger, S., Forwick, M., Gauger, S. and Lemenkova, P. (2006): The response of quaternary climatic 
cycles in the South-East Pacific: development of the opal belt and dynamics behavior of the West Antarctic ice sheet. In: K. Gohl (ed): Expeditionsprogramm Nr. 75 ANT XXIII/4, AWI. https://doi.org/10.13140/RG.2.2.11468.87687

LAdroit, Y., Escobar-Flores, P. C., Schimel A. C. G. and O'Driscoll, R. L. (2020): ESP3: An open-source software for the quantitative processing of hydro-acoustic data. SoftwareX 12: 100581. https://doi.org/10.1016/j.softx.2020.100581

Lawver, L. A., Gahagan, L. M. (2003): Evolution of Cenozoic seaways in the circum-Antarctic region. Palaeogeography, Palaeoclimatology, Palaeoecology, 198 (1-2): 11-37. https://doi.org/ 10.1016/S0031-0182(03)00392-4

Leat, P. T., Flowerdew, M. J., Riley, T. R., Whitehouse, M. J., Scarrow, J. H. and Millar, I. L. (2009): Zircon U-Pb dating of Mesozoic volcanic and tectonic events in north-west Palmer Land and south-west Graham Land, Antarctica. Antarctic Science, 21(6): 633-641. https://doi. org/10.1017/S0954102009990320

Leat, P. T., Jordan, T. A., Flowerdew, M. J., Riley, T. R., Ferraccioli, F. and Whitehouse, M. J. (2018): Jurassic high heat production granites associated with the Weddell Sea rift system, Antarctica. Tectonophysics, 722: 249-264. https://doi.org/10.1016/j.tecto.2017.11.011

Lemenkov, V., LemenKova, P. (2021a): Using TeX markup language for 3D and 2D geological plotting. Foundations of Computing and Decision Sciences, 46(3): 43-69. https://doi.org/ 10.2478/fcds-2021-0004

Lemenkov, V., LemenKova, P. (2021b): Measuring equivalent cohesion ceq of the frozen soils by compression strength using kriolab equipment. Civil and Environmental Engineering Reports, 31(2): 63-84. https://doi.org/10.2478/ceer-2021-0020

Lemenkova, P. (2011): Seagrass Mapping and Monitoring Along the Coasts of Crete, Greece. M.Sc. Thesis. Netherlands: University of Twente. 158 p. https://doi.org/10.13140/RG.2.2. 16945.22881

Lemenkova, P. (2019a): Statistical Analysis of the mariana trench geomorphology using R programming language. Geodesy and Cartography, 45(2): 57-84. https://doi.org/10.3846/ gac. 2019.3785

Lemenkova, P. (2019b): Testing linear regressions by StatsModel Library of Python for oceanological data interpretation. Aquatic Sciences and Engineering, 34: 51-60. https://doi.org/ 10.26650/ASE2019547010

Lemenkova, P. (2019c): GMT Based Comparative Analysis and Geomorphological Mapping of the Kermadec and Tonga Trenches, Southwest Pacific Ocean. Geographia Technica, 14(2): 3948. https://doi.org/10.21163/GT_2019.142.04

Lemenkova, P. (2019d): Geomorphological modelling and mapping of the Peru-Chile Trench by GMT. Polish Cartographical Review, 51(4): 181-194. https://doi.org/10.2478/pcr-2019-0015

LEMENKOVA, P. (2019e): AWK and GNU octave programming languages integrated with generic mapping tools for geomorphological analysis. GeoScience Engineering, 65(4): 1-22. https://doi. org/10.35180/gse-2019-0020

Lemenkova, P. (2020a): GEBCO Gridded Bathymetric Datasets for Mapping Japan Trench Geomorphology by Means of GMT Scripting Toolset. Geodesy and Cartography, 46(3): 98112. https://doi.org/10.3846/gac.2020.11524

LEMENKOVA, P. (2020b): Fractal surfaces of synthetical DEM generated by GRASS GIS module r.surf.fractal from ETOPO1 raster grid. Journal of Geodesy and Geoinformation, 7(1): 86-102. https://doi.org/10.9733/JGG.2020R0006.E

Lemenkova, P. (2020c): The geomorphology of the Makran Trench in the context of the geological and geophysical settings of the Arabian Sea. Geology, Geophysics and Environment, 46(3): 205-222. https://doi.org/10.7494/geol.2020.46.3.205

Lemenkova, P. (2020d): R Libraries \{dendextend and \{magrittr\} and Clustering Package scipy.cluster of Python For Modelling Diagrams of Dendrogram Trees. Carpathian Journal of Electronic and Computer Engineering, 13(1): 5-12. https://doi.org/10.2478/cjece-2020-0002

LEMENKova, P. (2020e): Integration of geospatial data for mapping variation of sediment thickness in the North Sea. Scientific Annals of the Danube Delta Institute, 25: 129-138. https://doi.org/10.7427/DDI.25.14 
Lemenkova, P. (2021a): Geodynamic setting of Scotia Sea and its effects on geomorphology of South Sandwich Trench, Southern Ocean. Polish Polar Research, 42(1): 1-23. https://doi.org/ $10.24425 /$ ppr.2021.136510

LEMENKOVA, P. (2021b): The visualization of geophysical and geomorphologic data from the area of Weddell Sea by the Generic Mapping Tools. Studia Quaternaria, 38(1): 19-32. https://doi.org/10.24425/sq.2020.133759

Lemenkova, P., Promper, C. and Glade, T. (2012): Economic assessment of landslide risk for the Waidhofen a.d. Ybbs Region, Alpine Foreland, Lower Austria. In: E. Eberhardt, C. Froese, A. K. Turner and S. Leroueil, (eds.): Protecting Society through Improved Understanding. $11^{\text {th }}$ International Symposium on Landslides \& the 2nd North American Symposium on Landslides \& Engineered Slopes (NASL), June 2-8, 2012. Canada, Banff: pp. 279-285. https://doi.org/ $10.6084 / \mathrm{m} 9$. figshare.7434230

Lindeque, A., Gohl, K., WobBe, F. and Uenzelmann-Neben, G. (2016): Preglacial to glacial sediment thickness grids for the Southern Pacific Margin of West Antarctica. Geochemistry Geophysics Geosystems, 17(10): 4276-4285. https://doi.org/10.1002/2016GC006401

Lindeque, A., Martos, Y. M., Gohl, K. and Maldonado, A. (2013): Deep-sea pre-glacial to glacial sedimentation in the Weddell Sea and southern Scotia Sea from a cross-basin seismic transect. Marine Geology 336: 61-83. https://doi.org/10.1016/j.margeo.2012.11.004

LyThE, M., VAUGHAN, D. G. and BEDMAP Consortium (2000): BEDMAP - Bed topography of the Antarctic, BAS Misc., 9 Edn., SCAR/BAS, Cambridge.

Lythe, M., Vaughan, D. G. and The BEDMAP Consortium (2001): BEDMAP: A new ice thickness and subglacial topographic model of Antarctica. Journal of Geophysical Research, 106: 11335-11352.

Motta, M., de Castro Neto, M. and Sarmento, P. (2021): A mixed approach for urban flood prediction using Machine Learning and GIS. International Journal of Disaster Risk Reduction, 56: 102154. https://doi.org/10.1016/j.ijdrr.2021.102154

NeTELER, M. (2000): GRASS-Handbuch, Geosynthesis 11. University of Hannover. Der praktische Leitfaden zum Geographischen Informationssystem GRASS

Neteler, M., Beaudette, D. E., Cavallini, P., Lami, L. and Cepicky, J. (2008): GRASS GiS. Chapter 9. In: G. B. Hall, M. G. Leahy (eds.): Open Source Approaches in Spatial Data Handling. Advances in Geographic Information Science. Springer-Verlag Berlin Heidelberg.

Riley, T. R., Jordan, T. A., Leat, P. T., Curtis, M. L. and Millar, I. L. (2020): Magmatism of the Weddell Sea rift system in Antarctica: Implications for the age and mechanism of rifting and early stage Gondwana breakup. Gondwana Research, 79: 185-196. https://doi.org/10.1016/ j.gr.2019.09.014

RogEnhagen, J., JoKAT, W. (2000): The sedimentary structure in the western Weddell Sea. Marine Geology, 168(1-4): 45-60. https://doi.org/10.1016/S0025-3227(00)00048-7

Rosenheim, B. E., Day, M. B., Domack, E., Schrum, H., Benthien, A. and Hayes, J. M. (2008): Antarctic sediment chronology by programmed-temperature pyrolysis: Methodology and data treatment. Geochemistry, Geophysics, Geosystems, 9: Q04005, https://doi.org/10.1029/ 2007GC001816

SANDwell, D. T., SMith, W. H. F. (2005): Retracking ERS-1 altimeter waveforms for optimal gravity field recovery. Geophysical Journal International, 163(1): 79-89. https://doi.org/ 10.1111/j.1365-246X.2005.02724.x

SANDWELl, D. T., SMITH, W. H. F. (2009): Global marine gravity from retracked Geosat and ERS1 altimetry: Ridge segmentation versus spreading rate. Journal of Geophysical Research, 114(B1): B01411. https://doi.org/10.1029/2008JB006008

Sandwell, D. T., Müller, R. D., Smith W. H. F., Garcia E. and Francis R. (2014): New global marine gravity model from CryoSat-2 and Jason-1 reveals buried tectonic structure. Science, 346(6205): 65-67. https://doi.org/10.1126/science. 1258213

Schenke, H. W., Lemenkova, P. (2008): Zur frage der meeresboden-kartographie: Die nutzung von autotrace digitizer für die vektorisierung der bathymetrischen daten in der Petschora-See. Hydrographische Nachrichten, 81: 16-21. https://doi.org/10.6084/m9.figshare.7435538 
SMith, W. H. F., SANDwell, D. T. (1995): Marine gravity field from declassified Geosat and ERS1 altimetry. EOS Transactions AGU, 76: F156.

Storey, B. C., Vaughan, A. P. M. and Riley, T. R. (2013): The links between large igneous provinces, continental break-up and environmental change: evidence reviewed from Antarctica. Earth and Environmental Science. Transactions of the Royal Society of Edinburgh, 104: 1-14. https://doi.org/10.1017/S175569101300011X

Straume, E. O., Gaina, C., Medvedev S., Hochmuth, K., Gohl, K., Whittaker, J. M., Abdul Fattah, R., Doornenbal, J. C. and Hopper, J. R. (2019): GlobSed: updated total sediment thickness in the World's Oceans. Geochemistry, Geophysics, Geosystems, 20(4): 1756-1772. https://doi.org/10.1029/2018GC008115

Suetova, I. A., Ushakova, L. A. and Lemenkova, P. (2005): Geoinformation mapping of the Barents and Pechora Seas. Geography and Natural Resources, 4: 138-142. https://doi.org/ 10.6084/m9.figshare.7435535

Takeda, A., Cox, S. and Payne, A. J. (2002): Parallel numerical modelling of the Antarctic Ice Sheet. Computers \& Geosciences, 28(6): 723-734. https://doi.org/10.1016/S0098-3004(01) 00106-6

Tedesco, M. (2009): Assessment and development of snowmelt retrieval algorithms over Antarctica from k-band spaceborne brightness temperature (1979-2008). Remote Sensing of Environment, 113: 979-997. https://doi.org/10.1016/j.rse.2009.01.009

Tigchelaar, M., Timmermann, A., Pollard, D., Friedrich, T. and Heinemann, M. (2018): Local insolation changes enhance Antarctic interglacials: Insights from an 800,000-year ice sheet simulation with transient climate forcing. Earth and Planetary Science Letters, 495: 6978. https://doi.org/10.1016/j.epsl.2018.05.004

Vaughan, A. P. M., Leat, P. T., Dean, A. A. and Millar, I. L. (2012): Crustal thickening along the West Antarctic Gondwana margin during mid-Cretaceous deformation of the Triassic intraoceanic Dyer Arc. Lithos, 142-143: 130-147. https://doi.org/10.1016/j.lithos.2012.03.008

Walther, B. A., Huettmann, F. (2021): Palearctic passerine migrant declines in African wintering grounds in the Anthropocene (1970-1990 and near future): A conservation assessment using publicly available GIS predictors and machine learning. Science of The Total Environment, 777: 146093. https://doi.org/10.1016/j.scitotenv.2021.146093

Wessel, P., Luis, J. F., Uieda, L., Scharroo, R., Wobbe, F., Smith, W. H. F. and Tian, D. (2019): The generic mapping tools version 6. Geochemistry, Geophysics, Geosystems, 20: 5556-5564. https://doi.org/10.1029/2019GC008515

WiLliams, R. (1987): Evolution in cartography: Data intelligence. Cartography, 16(2): 141-146. https://doi.org/10.1080/00690805.1987.10438364

Wobbe, F., Lindeque, A. and Gohl, K. (2014): Total sediment thickness grid of the Southern Pacific Ocean off West Antarctica, links to NetCDF files. Pangea, https://doi.org/10.1594/ PANGAEA. 835589

\section{Web sources / Other sources}

[1] British Antarctic Survey https://www.bas.ac.uk/ [access: 12.06.2021]

[2] GRASS Development Team (2018): Geographic Resources Analysis Support System (GRASS GIS) Software. Open Source Geospatial Foundation, USA. https://grass.osgeo.org [access: 05.12.2020].

[3] Geospatial Data Abstraction Library https://gdal.org/ [access: 12.06.2021] 